\title{
Level of Satisfaction of Mothers on the Health Services Provided by Midwives in the Different Birthing Centers in Tabuk City
}

\section{Nellie Valera Apatas}

\author{
Kalinga State University, Philippines
}

Received: 03 Oct 2020; Received in revised form: 15 Dec 2020; Accepted: 19 Dec 2020; Available online: 31 Dec 2020

C2020 The Author(s). Published by Infogain Publication. This is an open access article under the CC BY license

(https://creativecommons.org/licenses/by/4.0/).

\begin{abstract}
Quality care throughout pregnancy, intrapartum and postpartum period inclined the chances to decrease maternal mortality and morbidity rate mostly for women with complex needs. Midwives often required doing as an obstetrician, nurse and administrator meeting the needs of the pregnant women. The care of mother receives during pregnancy, intrapartum and early postnatal period plays a vital role in safeguarding women remain to be healthy and well-nourished through rendering good obstetrical services with a skilled and competent midwife.
\end{abstract}

The research aimed to study the level of satisfaction of mothers on the health services provided by Midwives in the different Birthing Centers in Tabuk City

A descriptive research design was used in the study. Frequency and percentage were applied in summarizing the profile variables of the respondents. Moreover, ANOVA and Chi square were used on the relationship of clients on the level of the satisfaction when grouped according to their profile variables. With the analysis of findings of this study it was concluded that there were significant differences on the level of satisfaction of mothers in terms of maternal health services on postnatal when grouped according to ethnic origin.

Keywords-Birthing centers, health services, midwives, Tabuk City.

\section{INTRODUCTION}

The United Nations under Millennium Development and World Health Organization 2010 Goal 5 emphasizing on the improvement of Maternal Health Care thus promote maternal health and provide quality services this aim is to reduce maternal mortality and morbidity rate all throughout pregnancy, delivery and postpartum period. As response to this global call, the Department of Health 2011 together with the mandate the Provincial and Rural Health Unit campaign continuously on providing maternal care.

The Department of Health 2011, established a maternal, neonatal and child health approach to develop quality care and increased the proportion of delivery in birthing centers and hospitals. Maternal satisfaction is one of the most important indicators for determining delivery of care thus patient satisfaction is influenced by a wide variety of aspects, such as accessibility, interpersonal, technical aspects, physical environment, and outcome of care. Hence, high patient satisfaction is associated with greater health awareness and health facility use influences continuity of healthcare utilization. Conversely, patient dissatisfaction with care has negative impacts on decisions to seek, access and receive adequate health care.

Moreover, the Department of Health Office Kalinga 2015 validated 48 GIDAS ( Geographically Isolated and Depressed Areas ) based on the physical factors wherein 25 
percent of the Barangay needs more than 60 minutes travel to the nearest birthing center to access their maternal services. The factors include isolation due to distance, weather conditions, transportation difficulties (island, upland, low land, landlocked, hard to reach and unserved). Due to the distance of birthing centers, pregnant mothers have struggling their selves to seek maternal care hence they prefer not to undergo prenatal services.

The City has one (1) Government Hospital, the Kalinga Provincial Hospital supposedly a level 2 health facility is currently licensed as Level I by the Department of Health with a 100 bed capacity hospital, serves as the core referral hospital of the zone and at same time the end referral hospital of the province and nearby provinces like Mountain Province and Isabela.

Tabuk City have three ( 3 ) Rural Health Unit comprises with two lying in or birthing centers and two ( 2 ) active private of which were expanded as birthing clinics . These birthing centers situated in the lower part of the locality. According to the City Health Office, birthing centers complied with the guidelines of Department of Health prenatal, intranatal and postnatal standard in 2017 mandated by the Department of Health to ensure safe pregnancy labor and delivery of mothers. Hence this will reduce the cases of pregnancy and birth related problem especially in the far flung areas during prenatal, intranatal and postnatal period.

This study delved on assessing the level of satisfaction on the health services provided by the midwives to mothers in the different birthing centers in Tabuk City. The result of this study will help improving the quality of care, evaluating the performances of midwives as well as improving midwifery practices in dealing with client.

\section{METHODOLOGY}

Collection of data done in different birthing homes within the City of Tabuk. Finalization of the research was carried out in Kalinga State University. It was conducted April 2019 to August 2019. The descriptive research method was used in the study. An interview and use of questionnare was used to gather primary data for this study. Data collected was compiled, analyzed and interpreted. The respondents of the study were postpartum mothers with legal ages who availed the services of the Birthing Center from the year 2017- 2018. A total of two hundred (220).The survey was conducted with 55 women per birthing homes both private and government birthing homes. A lifted questionnaire from the Department of Health 2009 on Maternal, Newborn and Child Health and Nutrition (MNCHN) was adopted and developed as the tool in gathering the data needed in the study. Questionnaires in the survey tool were translated in their vernacular so that the respondents were able to understand. Prior to conduct of the study a permission letter was given to the birthing homes administrator particularly to the Municipal Health Officer and Owner. Upon approval an informed consent given to the respondents, the researcher personally floated and collected the questionnaires to ensure validity, reliability and as well as confidentiality of answer from the respondents. Face to face interview were conducted in a place comfortable and convenient to the participants was also done. Frequency and Percentage was used in summarizing the profile variables of the respondents while weighted mean was used in analyzing the demographic profile of birthing centers in terms of type of birthing center and employed midwives as to birthing center and the level of satisfaction of mothers in terms on the services offered by the birthing centers in terms of prenatal, postnatal and treatment of respondents when group according to their profile variables. Lastly, Anova and Chi -test Square were used on the a significant relationship on the level of satisfaction of patients on the services offered by the birthing homes when respondents are group according to their profile variables. To determine the level of satisfaction of the respondents, a 5-points Likert scale was adopt and used. It was developed by the American educator and organizational Psychologist Rensis Likert in 1932 this improve the level of measurement in social research through the use of standardized response categories in survey questionnaires.

\section{RESULTS AND DISCUSSION}

Table 1. Frequency and Percentage Distribution of the Profile of the Respondents

1.1. Age.

\begin{tabular}{|c|c|c|}
\hline Age Bracket & Frequency & Percentage \\
\hline $21-25$ & 116 & 52.72 \\
\hline $26-30$ & 59 & 26.81 \\
\hline $31-35$ & 28 & 12.72 \\
\hline $36-40$ & 13 & 5.90 \\
\hline $41-45$ & 4 & 1.81 \\
\hline Total & $\mathbf{2 2 0}$ & $\mathbf{1 0 0}$ \\
\hline
\end{tabular}


Table 1 shows the frequency and percentage distribution of the profile of the respondents. Majority of the respondents were $21-25$ years old with $52.72 \%$. This explained that between this ages, mothers had utilized the birthing homes with adequate information on maternal health services while ages $41-45$ years old had $1.81 \%$ just because this age is high risk stage which can anytime may develop and lead into complications so they prefer to go to primary and secondary level hospital.

\subsection{Religion}

\begin{tabular}{|c|c|c|}
\hline Religion & Frequency & Percentage \\
\hline Anglican & 56 & 25.45 \\
\hline Iglesia ni Kristo & 18 & 8.18 \\
\hline Jehovas Witnesses & 9 & 4.09 \\
\hline Roman Catholic & 132 & 60 \\
\hline Seven Day Adventist & 5 & 2.27 \\
\hline Total & $\mathbf{2 2 0}$ & $\mathbf{1 0 0}$ \\
\hline
\end{tabular}

As to religion, the highest were Roman Catholic which is $60 \%$ since they were the largest population and believers in the location. The lowest is Seventh day Adventist were relatively new in the locality.

\subsection{Ethnic Origin}

\begin{tabular}{|c|c|c|}
\hline $\begin{array}{c}\text { Ethnic } \\
\text { Origin }\end{array}$ & Frequency & Percentage \\
\hline Bago & 12 & 5.45 \\
\hline Igorot & 44 & 20 \\
\hline Ilocano & 42 & 19 \\
\hline Kalinga & 122 & 55.45 \\
\hline Total & $\mathbf{2 2 0}$ & $\mathbf{1 0 0}$ \\
\hline
\end{tabular}

It is also seen in the table 1.3 that majority of the respondents were Kalinga with $45.33 \%$, it denotes that they were the common settlers in the area in which they were migrated from upper part of Kaling . The lowest is Bago this composed of the migrants from Cervantes and Mt. Province. Recently, Barangay Casigayan of Dagupan, Tabuk City was occupied by mostly Bago tribe members.

\subsection{Socio Economic}

The economic income of the respondents as seen in the table1.4, 5,001-10,000 the highest, since majority of the respondents were housewives, property-less and live on intermittent or seasonal works as rice planters, harvesters or care-takers, while $1.81 \%$ of them have income ranging from 20,001-25,000, this are the respondents where they have a job and regular income.

\begin{tabular}{|c|c|c|}
\hline Economic Income & Frequency & Percentage \\
\hline Below $5,000.00$ & 77 & 35 \\
\hline $5,001-10,000$ & 99 & 45 \\
\hline $10,001-15,000$ & 22 & 10 \\
\hline $15,001-20,000$ & 18 & 8.18 \\
\hline $20,001-25,000$ & 4 & 1.81 \\
\hline Total & $\mathbf{2 2 0}$ & $\mathbf{1 0 0}$ \\
\hline
\end{tabular}

1.5

\begin{tabular}{|c|c|c|}
\hline $\begin{array}{c}\text { Highest Educational } \\
\text { Attainment }\end{array}$ & Frequency & Percentage \\
\hline Elementary graduate & 94 & 42.72 \\
\hline High school graduate & 96 & 43.63 \\
\hline College level & 17 & 7.72 \\
\hline College Graduate & 11 & 5 \\
\hline Masters' degree & 2 & 0.90 \\
\hline Total & $\mathbf{2 2 0}$ & $\mathbf{1 0 0}$ \\
\hline
\end{tabular}

As to educational attainment, $43.63 \%$ of the respondents were High school graduate which is the highest, while $0.90 \%$ of them have master's degree. Majority of the respondents were high school graduate, this implies that majority of this age prefer and utilized the birthing centers in the locality compare to master's degree with $0.09 \%$.

Table 2. Profile of the Birthing Center

Table 2.1 Frequency and Percentage Distribution of Employed Midwife as to Birthing Homes

\begin{tabular}{|c|c|c|}
\hline $\begin{array}{c}\text { Type of } \\
\text { Birthing Home }\end{array}$ & Frequency & Percentage \\
\hline Government & 23 & 69.69 \\
\hline Private & 10 & 30.31 \\
\hline Total & $\mathbf{3 3}$ & $\mathbf{1 0 0}$ \\
\hline
\end{tabular}


Table 2.1 shows the frequency and percentage distribution of employed midwife as to birthing homes, $69.69 \%$ of the midwives were working in the government birthing homes while $30.31 \%$ of them work in the private birthing homes. This implies that there were adequate midwives working in the government birthing homes they can accommodate more pregnant mothers while in the private birthing homes had a scarcity of employed midwife, adequate midwives working in the government birthing homes and they can accommodate more pregnant mothers while in the private birthing homes had a scarcity of employed midwife

Table 2.2Frequency and Percentage Distribution of the Study as to Type of Birthing Homes

\begin{tabular}{|c|c|c|}
\hline $\begin{array}{c}\text { Type of } \\
\text { Birthing Home }\end{array}$ & Frequency & Percentage \\
\hline Government & 2 & 50 \\
\hline Private & 2 & 50 \\
\hline Total & $\mathbf{4}$ & $\mathbf{1 0 0}$ \\
\hline
\end{tabular}

Table 2.2 shows the frequency and percentage distribution of the study as to type of birthing homes, $50 \%$ of the birthing home were under the government while $50 \%$ a private birthing home. This implies that there were only four active birthing centers in the city to cater the needs of pregnant mothers.

Table 3. Level of Satisfaction of Mothers in terms of the Services offered by the Birthing Centers

Table 3.1. Mean distribution on the Level of Satisfaction of Mothers Offered by the Midwife during Prenatal

\begin{tabular}{|l|c|c|}
\hline \multicolumn{1}{|c|}{ Prenatal } & $\begin{array}{c}\text { Ave } \\
\text { - } \\
\text { an }\end{array}$ & Description \\
\hline $\begin{array}{l}\text { 1. Midwife follows the } \\
\text { scheduled prenatal check- } \\
\text { up. }\end{array}$ & 3.55 & $\begin{array}{l}\text { Moderately } \\
\text { Satisfied }\end{array}$ \\
\hline $\begin{array}{l}\text { 2. Poor health teaching } \\
\text { regarding the diet intake } \\
\text { during pregnancy. }\end{array}$ & 2.15 & Unsatisfied \\
\hline $\begin{array}{l}\text { 3. Conduct home of visit of } \\
\text { midwife if I cannot come } \\
\text { for checkup to birthing } \\
\text { home. }\end{array}$ & 2.03 & Unsatisfied \\
\hline
\end{tabular}

ISSN: 2456-7620

\begin{tabular}{|l|c|c|}
\hline $\begin{array}{l}\text { 4. Midwife discuss the } \\
\text { importance of prenatal } \\
\text { check-up }\end{array}$ & 3.52 & $\begin{array}{c}\text { Moderately } \\
\text { Satisfied }\end{array}$ \\
\hline $\begin{array}{l}\text { 5. Provide instruction } \\
\text { regarding schedule of my } \\
\text { next prenatal care. }\end{array}$ & 3.47 & $\begin{array}{l}\text { Moderately } \\
\text { Satisfied }\end{array}$ \\
\hline Categorical Mean & $\mathbf{2 . 9 4}$ & $\begin{array}{l}\text { Somehow } \\
\text { Satisfied }\end{array}$ \\
\hline
\end{tabular}

Table 3.1. The table shows the respondents were unsatisfied in terms of poor health teaching regarding the diet intake during pregnancy and conduct of home visit if the pregnant mother cannot go for checkup to birthing home the reason that midwives cannot do home visitation often because of the number of walk-in patient. Majority of the respondents are farming and house-hold works, pregnant mothers somehow made it secondary to their health, they forget the scheduled made and failed to visit the birthing home on such schedule. The overall categorical mean is 2.94 , clients were somehow satisfied because the maximum expected services to be delivered is not fully met because the mother also failed to proceed in the follow up check-up.

Table 3.2. Mean Distribution on the level of Satisfaction of mothers in terms of Postnatal Services

\begin{tabular}{|l|l|l|}
\hline Postnatal immediate & $\begin{array}{l}\text { Ave. } \\
\text { Mean }\end{array}$ & Description \\
\hline $\begin{array}{l}\text { 1.Encourage } \\
\text { exclusive } \\
\text { breastfeeding to }\end{array}$ & $\begin{array}{l}\text { Moderately } \\
\text { Satisfied }\end{array}$ \\
\hline $\begin{array}{l}\text { 2.Proper to } \\
\text { hygiene/douching } \\
\text { postpartum mothers }\end{array}$ & 3.73 & $\begin{array}{l}\text { Moderately } \\
\text { Satisfied }\end{array}$ \\
\hline $\begin{array}{l}\text { 3. Good counseling on the } \\
\text { importance of breastfeeding }\end{array}$ & 3.54 & $\begin{array}{l}\text { Moderately } \\
\text { Satisfied }\end{array}$ \\
\hline $\begin{array}{l}\text { 4. Observe aseptic } \\
\text { technique during the } \\
\text { cleaning of my perineal } \\
\text { wound. }\end{array}$ & $\begin{array}{l}\text { Moderately } \\
\text { Satisfied }\end{array}$ \\
\hline $\begin{array}{l}\text { 5. Provide counseling on a } \\
\text { range of option for Family } \\
\text { Planning }\end{array}$ & 1.95 & Unsatisfied \\
\hline Categorical Mean & 3.15 & $\begin{array}{l}\text { Somehow } \\
\text { Satisfied }\end{array}$ \\
\hline
\end{tabular}

Table 3.2 The table shows that the respondents were moderately satisfied in terms of encouraging immediate exclusive breastfeeding with 3.73 . This implies that 
information education regarding breastfeeding is explained well to the respondents.

Providing counseling on the range of option for family planning were unsatisfied. This implies that the midwives did not properly discussed the different method of contraceptives before the discharge of patient. The general outlook shows that the postnatal services are rated by the respondents as somehow satisfied.

Table 3.3. Mean Distribution on the level of Satisfaction of mothers in terms of treatment.

\begin{tabular}{|l|c|c|}
\hline Treatment /Medicine & $\begin{array}{c}\text { Ave. } \\
\text { Mean }\end{array}$ & Description \\
\hline $\begin{array}{l}\text { 1. Explain the taking in of } \\
\text { medicines like vitamins. }\end{array}$ & 3.46 & $\begin{array}{c}\text { Moderately } \\
\text { Satisfied }\end{array}$ \\
\hline $\begin{array}{l}\text { 2. Explain the side effects of } \\
\text { the medicines/vitamins. }\end{array}$ & 3.45 & $\begin{array}{c}\text { Moderately } \\
\text { Satisfied }\end{array}$ \\
\hline $\begin{array}{l}\text { 3. Midwives administered } \\
\text { maternal immunization as } \\
\text { scheduled. }\end{array}$ & 3.57 & $\begin{array}{c}\text { Moderately } \\
\text { Satisfied }\end{array}$ \\
\hline
\end{tabular}

\begin{tabular}{|l|c|c|}
\hline $\begin{array}{l}\text { 4. Explain the use and } \\
\text { importance of folic acid to me } \\
\text { and to my baby. }\end{array}$ & 2.52 & Unsatisfied \\
\hline $\begin{array}{l}\text { 5. All needed medicine } \\
\text { /Vitamins are available in } \\
\text { birthing center. }\end{array}$ & 3.43 & $\begin{array}{c}\text { Moderately } \\
\text { Satisfied }\end{array}$ \\
\hline \multicolumn{1}{|c|}{ Categorical Mean } & $\mathbf{3 . 2 8}$ & $\begin{array}{c}\text { Somehow } \\
\text { Satisfied }\end{array}$ \\
\hline
\end{tabular}

As gleaned in the table 3.3 it implies the midwives were able to administer maternal immunization as scheduled with an average mean of 3.57, it denotes that they follow the interval of the immunization given to pregnant mother. As to explain the use and importance of folic acid to me and to my baby with an average mean of 2.52 which is the lowest, this means that they did not explain very well the benefits of the vitamins to both mother and baby thus it has to be given more attention for the mothers to fully understand the significance of the medicine /vitamins for their babies

Table 4. Relationship on the Level of Satisfaction of Mothers on the services offered by the Birthing Homes and their Profile Variables.

\begin{tabular}{|c|c|c|c|}
\hline Profile /Variables & $\begin{array}{c}\text { Chi squared } \\
\text { test }\end{array}$ & Probability & Decision \\
\hline \multicolumn{4}{|l|}{ Prenatal } \\
\hline Age & 2.851 & 0.5830 & Not Significant \\
\hline Religion & 10.826 & 0.0939 & Not Significant \\
\hline Ethic Origin & 1.020 & 0.7965 & Not Significant \\
\hline Economic Income & 1.714 & 0.7881 & Not Significant \\
\hline $\begin{array}{l}\text { Highest Educational } \\
\text { Attainment }\end{array}$ & 1.550 & 0.8177 & Not Significant \\
\hline \multicolumn{4}{|l|}{ Postnatal } \\
\hline Age & 2.639 & 0.6199 & Not Significant \\
\hline Religion & 3.855 & 0.6963 & Not Significant \\
\hline Ethic Origin & 13.614 & $0.0035 *$ & Significant \\
\hline Economic Income & 1.714 & 0.7881 & Not Significant \\
\hline $\begin{array}{l}\text { Highest Educational } \\
\text { Attainment }\end{array}$ & 1.550 & 0.8177 & Not Significant \\
\hline \multicolumn{4}{|l|}{ Treatment } \\
\hline Age & 3.758 & 0.4398 & Not Significant \\
\hline Religion & 7.095 & 0.3121 & Not Significant \\
\hline
\end{tabular}




\begin{tabular}{|l|c|c|c|}
\hline Ethic Origin & 0.8746 & 0.6072 & Not Significant \\
\hline Economic Income & 1.836 & 0.3740 & Not Significant \\
\hline $\begin{array}{l}\text { Highest Educational } \\
\text { Attainment }\end{array}$ & 1.958 & 0.7434 & Not Significant \\
\hline
\end{tabular}

Table 4 shows the relationship on the level of satisfaction of mothers on the services offered by the birthing homes and their profile variables. A Chi-Square was employed with 0.05 level of significance. It was found to be significant under ethic origin in the postpartum with probability value of 0.0035 on postpartum services. This implies that there is a significant difference on the level of satisfaction of mothers in term of maternal health services on postnatal services when grouped according to ethnic origin. This is because the residents in Tabuk City came from different tribe with dissimilar cultural background and perception. In addition, indigenous people like Kalinga or the "Binodngan "and Igorot which mostly reside in Tabuk City were not ostentatious. They usually resume their normal household activities and they don't want to be served because they believed that giving birth is just a normal phenomenon. The ethnic origin of Ilocano and Bago is likely obedience to their beliefs and practices since they were particular on the health practices of newly gave birth thus postpartum selfdiscipline just after delivery is being practiced. The woman will only resume her household work only after she rest for a couple of months. Results shows that pre natal and post natal treatment have negative relationship on the level of satisfaction of patients from the services given by the birthing homes.

\section{CONCLUSION}

Based on the summary of findings, the researcher conclude that there were scarcity of employed midwives in the private birthing homes. There were also insufficient government birthing centers especially on the upper part of the locality. These can an attributed factors that affect the delivery of quality health services of midwives among their clients. Moreover, the chosen variables of the respondents are contributing aspect on the level of satisfaction of their client.

\section{RECOMMENDATION}

Based on the result of the study, it is recommended that administrators and owners of birthing homes of private birthing homes should employ more midwives to provide the needs of the community to ensure the maximum satisfaction and quality of services offered. Establish additional government birthing home to cater the needs of the community especially pregnant women.

\section{REFERENCES}

[1] Annama Jacob (2005) " A comprehensive Textbook of Midwifery $1^{\text {st }}$ Edition, Jaypee Publisher ,New Delhi .

[2] Anika Karistrom, Astrid Nystedt (2011) A Comparative Study of the Experience of Childbirth between Women who preferred gave birth in the Birthing Homes, A journal of Maternity Nursing, Vol.15No.33

[3] Alhusban MA (2009) the Patient Satisfaction with nursing care in Jordan, Journal of Management, Volume 17.Page 6

[4] Department of Health No Home Birthing Policy, Rosalinda L. Orosa March 4, 2013

[5] Diana M. Fraser, Margarett A. Cooper ( 2009 ) Myles Textbook of Midwifery 15 th Edition, Churchill Livingstone Publication, New Delhi

[6] Department of Health Philippines Addresses Maternal and Health Services thru MANCHAN program 2015 WWW.Ugnayan .Com.

[7] Department of Health Philippines National Safe Motherhood https://www.doh.gov.ph

[8] Groberna -Tricas (2011) Satisfaction with Pregnancy and Birth services .The quality of maternity care services as experienced by the woman, Journal of Midwifery, volume 8 N0.2on Antenatal care women of Jempol, Negeri ,Sembilan ,Malaysian J. Public Health Med .2011 ;11 (2) 13-21.

[9] Hala Bawasi (2009) Muslims women experienced of child birth, Journal Maternity Nursing Vo.10 No.6

[10] Larrsson BW, Kvist L.J Berg 2011 Swedish women' perception of their Intrapartal Care during

[11] Planned Vaginal Birth, International Journal of Health Care , Volume 24 ,No. 4

[12] Madeleine T. King (2004) Satisfaction with Intranatal Care,Journal of Midwifery, Volume 9, No.2 PP 146-153

[13] Maternal Mortality in the Philippines and the United nations Millennium Development goals by Genna Preston August 20, 2014 